\title{
IMPROBIDADE ADMINISTRATIVA E O FORO PRIVILEGIADO: OFENSA CONSTITUCIONAL
}

\author{
ALLAN MARTINS FERREIRA \\ PEDRO FONSECA GILL
}




\title{
IMPROBIDADE ADMINISTRATIVA E O FORO PRIVILEGIADO: Ofensa Constitucional
}

\author{
ALLAN M. FERREIRA ${ }^{1}$ \\ PEDRO FONSECA GILL ${ }^{2}$
}

\section{RESUMO}

0 presente trabalho destina-se a analise da improbidade administrativa sob o enfoque constitucional e sob a ótica da Lei 8429/92, que açambarcou no seu raio de ação agentes públicos comuns assim como os agentes políticos, acertadamente. Contudo, a partir de condenações de figuras que compõe a elite de mando na sociedade brasileira, de prefeitos a ministros de estado, em juízos de primeiro grau, os efeitos benfazejos da citada lei passaram a incomodar, a ponto de, o segundo Tribunal em importância do país passar a adotar a tese equivocada de que os atos de improbidade administrativa correspondem exatamente as hipóteses previstas para os crimes de responsabilidade, daí a incompatibilidade de coexistirem dois julgamentos em face de um mesmo fato. Nesse mesmo sentido, a Corte maior do país julgou caso de um ex-ministro de Estado, possibilitando com isso uma possível zona de imunidade, incompatível com os postulados republicanos e democráticos firmados e reafirmados pela Constituição de 88. De mais a mais, situar os agentes políticos fora do alcance da Lei 8429/92 representaria também clara ofensa aos princípios constitucionais da isonomia e da moralidade administrativa. Entretanto, o voto-vista do Ministro Joaquim Barbosa, na Reclamação 2138 (caso Sardenberg), apesar de vencido, mostrou-se repleto de

\footnotetext{
${ }^{1}$ Juiz de Direito no Tocantins, Pós Graduado em Direito Processual Civil pela UCS/UNITINS, pósgraduando em Direito Constitucional da UNITINS - Fundação Universidade do Tocantins. E-mail: allanmferreira@uol.com.br. ${ }^{2}$ Assessor Jurídico do Procurador Geral do Estado do Tocantins. Graduado em Direito pela Universidade Luterana do Brasil, pós-graduado em Ciência Política e Meio Ambiente pela UFT - Universidade Federal do Tocantins, pós-graduando em Direito Constitucional da UNITINS - Fundação Universidade do Tocantins. E-mail: palgilbr@vahoo.com.br. Texto

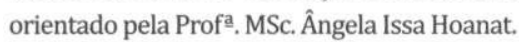


coerência e reparador do mal que poderia representar para o combate à corrupção neste país. Em julgamento seguinte, relativo ao ex-prefeito Paulo Maluf, tratando praticamente da mesma matéria, ou seja, da possibilidade de extensão do foro privilegiado aos agentes políticos, cujo relator foi o mesmo Joaquim Barbosa, o STF, já com nova composição, deixou claro que não seguira o entendimento firmado na aludida Reclamação 2138, o que não deixa de ser confortante, ao se saber que os princípios constitucionais valorizados e prestigiados pela Constituição de 88 serão resgatados e preservados. Este, pois é o objetivo do presente trabalho, ou seja, o de demonstrar que a melhor interpretação constitucional é aquela que respeita os princípios consagrados na Constituição de 88, e de que o foro privilegiado, na visão do senso comum, é causa de descrença nas instituições democráticas pela impressão e conotação de que é sinônimo de impunidade e pela evidência de que os principais gestores e altas autoridades da República nunca são sequer julgados, quanto mais condenados. Por fim, gera a mesma impressão a pretensa equiparação dos crimes de responsabilidade aos atos de improbidade, porque tal posição, na prática, corresponde a impossibilidade de resgate dos prejuízos causados ao erário pelos que detém o privilegio de foro, circunstância que causa perplexidade e justa indignação.

\section{Palavras-chave:}

Foro privilegiado - moralidade administrativa - agentes políticos impunidade - princípios constitucionais - interpretação constitucional.

\section{ABSTRACT}

This work intends to analyze the improper administrative action under the constitutional perspective and the Law 8429/92, which included in its area of influence ordinary public officials as well as the common political players. However, due to the sentencing of important people that represent the high social class, mayors and ministers and governors, the effects of that healthy law began to disturb some. 
According to the court that presents the importance of the improper administrative action and responsibility crime, there are two trials in the responsibility area in the light of the same fact. In this sense the Brazilian Supreme Court judged the case of a former minister of state, leading to a possibility to create a gray zone of immunity, which is not compatible with democracy and the republic society. Putting the political agents out of the reach of the law 8429/92 represents a clear offense to the constitutional principles and administrative moralities. In another trial related to the case of a former Sao Paulo city mayor regarding the same subject or the possibility of extension of the privilege forum to the political agents. The new composition of the Supreme Court made clear that would not follow the established understanding. Therefore the object of this work is to demonstrate that the best constitutional interpretation is the one that respects the principles of the constitutional of 1988 , and also that the privileged forum is the cause of disbelief in the democratic institutions - a synonym of impunity of the high authorities of the republic who are neither judged nor condemned. At last the match of two topics in fact corresponds to the impossibility to rescue the damages caused to the public treasury by the ones who have the privileges of this foro, causing perplexity and indignation to us all.

\section{Key words:}

privileged foro - administrative morality - political agents - impunity - constitutional principles - constitutional interpretation 


\section{INTRODUÇÃo}

A origem do presente trabalho decorreu da preocupação dos autores com os rumos que tem sido dado ao tema da improbidade administrativa, no particular aspecto da responsabilização dos agentes políticos. Sabe-se que os mesmos gozam do chamado foro privilegiado. Entretanto, essa prerrogativa é restrita, conforme a Constituição Federal, à esfera penal, quando da prática de crimes comuns ou de responsabilidade, estes reconhecidos como infrações político-administrativas, ou ainda, quando figurarem como agentes coatores em ações de mandado de segurança ou habeas corpus.

A idéia central, desde artigo é demonstrar, àluz da melhor interpretação constitucional, que não se justifica ser dispensado tratamento diferenciado a agentes políticos, livrando-os do alcance da Lei $8429 / 92$, enquanto que para o os demais agentes públicos sua aplicação continuaria válida e impositiva.

A moralidade administrativa, enquanto princípio constitucional instituído e densificado pela legislação infraconstitucional, repugna atos de improbidade administrativa, cuja reparação tem natureza eminentemente civil, consoante as mais abalizadas doutrinas. Todos os atores responsáveis pela gestão dos negócios públicos, sejam agentes políticos ou não, devem ser atingidos pelas sanções correspondentes aos atos atentatórios da moralidade pública, previstos na Lei 8429/92, sob pena de incorrer-se, com tal pretensa distinção, em ofensa clara a uma plêiade de princípios constitucionais inscritos na Carta de 88, e passe livre para a impunidade. Será realçada a circunstância de que as responsabilidades, civil, penal e administrativa não se confundem.

A pesquisa em questão teve basicamente como objeto a análise de teses doutrinárias e recentes julgamentos pelos Tribunais Superiores, utilizando-se da metodologia na pesquisa bibliográfica, lançando-se mão do método dedutivo, onde procuramos tratar do tema à luz de atualizada exegese constitucional, concluindo que a 
tese de que os atos de improbidade administrativa ficam absorvidos pelos crimes de responsabilidade não se sustenta.

Nesse sentido, este trabalho terá a finalidade de abordar o tema da improbidade e do foro privilegiado através de breve escorço histórico, passando pelo fundamento constitucional do combate à improbidade e das razões de sua existência; da essencialidade desse combate para a manutenção do regime republicano e democrático, e respeito ao princípio da igualdade, que em essência deve ser materialmente dispensado a todos os agentes que lidem com o patrimônio público.

Será analisado o caso Sardenberg e os seus equívocos e, por fim, a luz que surgiu no fim do túnel: o voto do Min. Joaquim Barbosa na petição 3923, movida pela defesa do ex-prefeito Paulo Maluf, cujo voto teve fundamentos parecidos com os contidos no seu voto proferido na Reclamação 2138 (a Lei 8429 tem aplicação aos agentes políticos, independente ocorrência do crime de responsabilidade), no que foi acompanhado pela maioria dos membros do STF em sua atual composição. Serão analisados casos específicos julgados pelo STJ e STF e demonstrado que a PEC n. 358, na parte em que pretende estender o foro para os atos de improbidade administrativa e para ex-autoridades nos crimes comuns é, materialmente inconstitucional, conforme a melhor interpretação constitucional, baseada, dentre outras, na lição de Dworkim. Como conclusão, sugere-se a adoção da solução apontada no voto do Min. Joaquim Barbosa ou a criação de um Tribunal Superior da Probidade, conforme proposta em curso na Câmara Federal.

\section{ESCORCO HISTÓRICO DO FORO PRIVILEGIADO EM MATÉRIA PENAL. DA MONARQUIA ABSOLUTISTA E IRRESPONSÁVEL À REPÚBLICA: UMA QUEBRA FORMAL DE PARADIGMA}

0 foro privilegiado remonta à última fase do império romano 
(séc. V), quando, por influência do direito canônico, foi transmudado para o julgamento de senadores quando praticassem algum crime, ocorrendo o julgamento pelos próprios pares.

No Brasil, nem mesmo sob o manto da Constituição Imperial de 1824, era admitido o foro privilegiado para outra jurisdição diversa da penal.

Com a proclamação da República, a Constituição de 1891 delimitou o foro privilegiado em função de duas categorias bem definidas, quais sejam, uma de crimes comuns e outra de crimes de responsabilidade.

Esse modelo se reproduziu nas demais constituições, com algumas variações, mas jamais, contemplou-se o foro por prerrogativa de função em matéria de responsabilidade civil ou extrapenal.

Sabido que as raízes históricas do foro privilegiado têm fundamento em razão do oficio da autoridade a que se destina, seu objetivo é manter uma certa simetria entre o status do órgão julgador e a autoridade julgada, a fim de se assegurar a independência do julgamento.

Até Montesquieu, autor da teoria da separação dos poderes, mas integrante da nobreza que era, defendeu o foro privilegiado, conforme citado por Luigi Ferrajoli na obra Dirito e Ragione, p. 673, justificando-se:

\footnotetext{
“Os grandes estão sempre expostos à inveja e, se fossem julgados pelo povo, poderiam encontrar-se em perigo e não gozariam da garantia que, em estado livre, é devida até ao mais humilde dos cidadãos, de ser julgado por seus pares. É necessário, portanto, que os nobres sejam denunciados não diante dos tribunais ordinários da nação, mas diante daquela parte do legislativo que é composta por nobres". ${ }^{2}$
}

No período pré-revolução francesa valia a regra da total irresponsabilidade do governante. Luis XIV, na Franca, tornou célebre a

\footnotetext{
${ }^{2}$ www.crimesdocolarinhobranco.adv.br
} 
frase "O Estado sou eu", dando a exata dimensão, ou falta de dimensão, do seu poder.

No Brasil, já no Império, a figura do Imperador era também indene de qualquer responsabilidade, conforme lhe assegurava o artigo 99 da Constituição: "A pessoa do Imperador é inviolável, e Sagrada: Ele não está sujeito a responsabilidade alguma”.

Sob o signo da República, que tem na responsabilidade do agente público um dos seus esteios, pelo menos se afasta a irresponsabilidade funcional dos governantes.

A nossa República, como se sabe, dec orreu de um ato de promulgação, sem a efetiva participação popular.

A idéia de República, pois, não passava pelas prioridades da população, de maneira que talvez o mote central do republicanismo, o qual tem na responsabilidade do agente público um dos seus pilares, não tenha sido contemplado com o especial cuidado, permitindose uma frouxidão no controle dos atos dos agentes públicos, desde e sempre, embora prevista a responsabilidade dos governantes na Carta Constitucional que se seguiu.

Na verdade o poder das elites sempre foi preservado, seja através do foro privilegiado, seja pela falta mesmo de qualquer controle efetivo sobre os atos desregrados de certos governantes e agentes políticos.

$\mathrm{Na}$ atualidade, entretanto, as chamadas prerrogativas de foro se compadecem cada vez menos com a evolução do regime democrático decorrentes da Constituição de 88.

Mesmo assim, por tradição e levando em conta motivações de preservação da função, a prerrogativa de foro, somente em matéria penal, vem se mantendo entre nós. Embora não seja este o objeto de preocupação deste estudo, deve-se registrar que, o grande problema do foro privilegiado é que, na prática, a teoria, é outra e o instituto do foro privilegiado, em si mesmo, tem se mostrado verdadeiro estuário de impunidades. 
E pior, algumas vozes já se manifestam no sentido de que o foro por prerrogativa de função deveria se estender para o campo cível, especialmente no tocante as milhares de ações por improbidade que correm frente aos juízos comuns, como será visto adiante.

Na verdade, é constatação evidente que a banalização do foro privilegiado, dentre outras coisas, tem servido para emprestar aos ímprobos mecanismos de triagem de seus julgadores e, principalmente acusadores. ${ }^{3}$

\section{A IMPROBIDADE: MAL CONGÊNITO NA FORMAÇÃO DA CULTURA BRASILEIRA}

Infelizmente, faz parte da cultura brasileira, a nefasta e vil prática de assacar os cofres públicos, seja diretamente em proveito próprio, ou mediante favores públicos a terceiros, as expensas ilegítimas e imorais do erário. A elite econômica e política, faz desta um meio de sobrevivência a custa da miséria de milhões de excluídos, gerando a cada dia que passa um aumento no fosso social que separa os ricos dos pobres.

Essa tradição malsã é retratada na obra de Raimundo Faoro ao citar passagem de uma missiva ácida e irônica, de Padre Antônio Vieira, que nos tempos do Brasil Colônia já informava: "Perde-se o Brasil, Senhor (digamo-lo numa palavra), porque alguns Ministros de sua Majestade não vêm buscar o nosso bem, vem cá buscar os nossos bens". ${ }^{4}$

Wallace Paiva Martins Júnior, anota, em análise ampla e profunda sobre as causas desse estado de permissividade e leniência instalado e a falta de reação social no trato e respeito com a coisa pública, o seguinte:

\footnotetext{
${ }^{3}$ WWW.anprorg.br. Boletim dos Procuradores da República. N. 55. “Da inconstitucional hipertrofia do Procurador Geral da República".

${ }^{4}$ FAORO. Raimundo. Os donos do Poder. Globo. Porto Alegre. 1976.
} 
"A deturpação tradicional do poder disseminou na sociedade brasileira a inconveniente, insuportável e incômoda cultura da improbidade administrativa, pela qual os maiores e mais gritantes escândalos eram vistos com passividade geral como decorrência da naturalidade das coisas, como se fosse absoluta, elementar e naturalmente lícitos aos agentes públicos a obtenção de vantagens ilícitas, o malbaratamento dos recursos do erário, o vilipêndio aos princípios da Administração Pública e o desprezo aos direitos e garantias individuais e sociais. Causas inúmeras (algumas atávicas, implantadas na fase do colonialismo português) contribuíram para esse estado de coisas, notamente porque o Estado brasileiro e excessivamente tutelar, demasiadamente burocrático e radical interveniente no atacado e no varejo das relações sociais".

Mas não seremos os primeiros nem os últimos em matéria de corrupção. Num rol de 180 países pesquisados pela ONG Transparência Internacional o Brasil ocupa a 72a segunda colocação de países mais corruptos, posição nada confortável, que necessita com urgência ser debelada através de leis e ações eficazes no combate a esse mal que tanto incomoda.

\subsection{AS RAÍZES DO PROBLEMA}

De um modo geral, os estudiosos no assunto creditam parte desses desvios à intervenção do Estado na ordem econômica e a sua atuação na ordem social, o que é, em certa medida, verdadeiro, mas há também o problema da aceitação social de condutas imorais, o mau nível salarial dos servidores públicos, a lentidão e acomodação dos órgãos públicos responsáveis pela fiscalização e controle das atividades públicas, aí incluídos Tribunais de Contas, Controladorias, e o próprio Ministério Público, bem como pelos vícios e esquemas espúrios de financiamento eleitorais, onde antes mesmo de o candidato se eleger, já fez compromissos dos mais imorais e perniciosos, contando

\footnotetext{
${ }^{5}$ JÚNIOR, Wallace Paiva Martins.Probidade Administrativa. 3a Ed. Saraiva. P. 2
} 
sempre como lastro com o patrimônio público. E, por fim, deve-se reconhecer, a existência do foro privilegiado.

Imagine-se todas as ações por improbidade contra prefeitos e autoridades com foro privilegiado concentradas em Tribunais de Justiça. A titularidade para a propositura da ação respectiva è restrita ao Procurador Geral de Justiça, ou a Procurador por ele indicado, os quais serão também responsáveis por acompanhar o processamento dessas milhares de ações contra prefeitos dos mais longínquos municípios, e outros que tais. Distantes da realidade das provas e das pessoas. Por outro lado, os tribunais responsáveis pela instrução processual das mesmas ações, cuja vocação não é naturalmente a de juízos de instrução, estando os mesmos abarrotados de recursos para ser julgados. Ademais, o tempo a ser gasto nessas instruções poderão significar definitivamente a bancarrota do sistema de apuração e punição dos atos de improbidade, redundando invariavelmente em impunidade, ou pelo menos, na clara sensação de que tudo não passa de um faz de conta.

\section{2. $O$ COMBATE À IMPROBIDADE: FUNDAMENTOS CONSTITUCIONAIS. MODALIDADES}

Por certo, a sobrevivência do Estado Democrático de Direito impõe, necessariamente, a proteção da moralidade e da probidade administrativa nos atos administrativos em geral, exaltando-se as regras de boa administração e defenestrando da gestão dos negócios públicos agentes que ostentem inaptidão moral para o exercício das funções públicas.

Na realidade, a corrupção generalizada na esfera pública gera a desconfiança nas instituições democráticas e é causa constante de instabilidade política e de crises de governabilidade.

Na história da nossa república, até bem pouco tempo, o legislador nunca havia se dedicado, nem se empenhou, de modo claro e preciso em punir os faltosos com o erário público. 
Em boa hora, o Constituinte de 88, inseriu no texto constitucional uma série de princípios e de valores encadeados entre si, norteadores das funções do estado. Dentre esses princípios está o da moralidade administrativa.

Anterior a isso, a ofensa à moralidade administrativa era vista apenas como crime de responsabilidade do Presidente da República ou de prefeitos. Agora, a idéia de probidade ganha novas feições, além de elevar a moralidade como princípio, emprestando às sanções correspondentes aos atos de improbidade natureza civil, cuidando o legislador ordinário de abranger o raio de ação para todos os agentes públicos e até estranhos que participem, incentivem ou de qualquer modo contribuam para a prática do ato de improbidade, ou dele se beneficiem, consoante estabelecido na legislação pertinente.

Conforme a Lei 8429/92, que regulamentou o artigo 37, par. $4^{\circ}$ da CF, a improbidade administrativa e tratada sob três vertentes: a) a que causa enriquecimento ilícito; b) a que causa dano ao erário e c) a que atenta contra os princípios da Administração. Todas com o fim precípuo de proteger o patrimônio público.

De acordo com aquele estatuto, as sanções foram além das previstas no texto constitucional, com propriedade, já que neste foi prevista a suspensão dos direitos políticos, a perda da função pública, a indisponibilidade dos bens e o ressarcimento ao erário, para naquele incluir, além destas, a multa civil e a proibição de contratar com o poder públi co ou de receber benefícios fiscais ou creditícios, além de outras medidas de natureza cautelar.

Por dez anos desde a edição da lei andou-se até que razoavelmente bem em matéria de punição dos atos de improbidade, até que altas autoridades do governo federal começaram a responder e a efetivamente serem condenadas por atos de improbidade. 


\section{O RETROCESSO: A TENTATIVA DE INVALIDAR O ALCANCE DA LEI 8.429/92 AOS AGENTES POLÍTICOS}

Como visto, o legislador se empenhou em densificar o princípio constitucional da moralidade e seus valores correspondentes, através da Lei 8.429/92, definindo os atos de improbidade, o processamento da ação correspondente, a legitimidade ativa e passiva para a ação, incluindo-se todos os agentes públicos, sem excepcionar os agentes políticos, na melhor leitura do texto constitucional.

Contudo, importantesh vozes passaram a tentar dar, por vias reflexas, verdadeira imunidade a determinado grupo de pessoas, que compõe ou integram os altos postos da república, e por simetria, as demais autoridades nos níveis estadual e municipal, os chamados agentes políticos, ao menos na esfera civil, com a clara intenção de lhes suprimir o alcance da Lei 8.429/92.

0 esdrúxulo argumento usado é o de que, por já estarem sujeitos aos regramentos da Lei 1079/50 ou aos do Decreto-lei $n^{\circ}$. 201/67, que tratam dos crimes de responsabilidade ou das infrações Políticoadministrativas, não poderiam se submeter aos preceitos daquela Lei, visto que tratariam ambas de matéria de mesmo conteúdo, significando a submissão aos dois diplomas àquelas autoridades em bis in idem, vedado pelo ordenamento jurídico, conforme afirmam.

Além disso, passaram a argumentar que o foro por prerrogativa de função deveria ser mantido para os atos de improbidade administrativa por analogia ao já estipulado na Constituição para os casos de crimes comuns e de responsabilidade (art. 102, I , a, b e c; art. 53, par. $1^{\circ} ; 96$, III, 108, I , a e art. 29, X, dentre outros).

\subsection{CASO JULGADO PELO S TJ: POSIÇÃO REACIONÁRIA}

Nesse sentido, em julgamento recente ${ }^{6}$, com voto divergente do

\footnotetext{
${ }^{6}$ STJ. RESP 456649-MG. DJU 5/09/06 “ADMINISTRATIVO. AÇÃO CIVIL PÚBLICA. EX-PREFEITO CONDUTA OMISSIVA. CARACTERIZAÇÃO DE INFRAÇÃO POLÍTICO ADMINISTRATIVA. DECRETO LEI 201/67. COEXISTÊNCIA IMPOSSIBILIDADE. MANUTENÇÃO DO ACÓRDÃO RECORRIDO. VOTO DIVERGENTE DO RELATOR".
} 
Min. Luiz Fux, por maioria, o STJ deixou claro que o regramento da Lei 8,429/92 não atingiria os agentes políticos, tomando como base lição doutrinária de Arnold Wald e de Gilmar Mendes.

Os fundamentos utilizados, dentre outros, eram o de que os atos de improbidade administrativa referidos na Lei 8429/92 correspondiam às mesmas condutas recriminadas pelo decreto-lei 201/67, não podendo haver enquadramento simultâneo. Afirmou-se que os ilícitos previstos na Lei de Improbidade Administrativa (LIA) encerravam os delitos de responsabilidade quando perpetrados por agentes políticos, diferenciando-se daqueles perpetrados por servidores em geral.

Clara e cinicamente, assegurou-se que os agentes políticos, por exercerem parcela da soberania estatal, estariam indenes à ação de improbidade administrativa, sujeitando-se somente ao regime dos crimes de responsabilidade. Mais adiante, valendo-se de casuísmo e de um argumento sofrível, para não dizer sofismático, citou-se a possibilidade e apontou-se para a gravidade de um juiz de primeiro grau poder decretar a destituição de um Ministro do STF, aplicando-lhe a perda da função por até dez anos, concluindo que esta seria uma solução incompatível com o sistema instituidor do foro por prerrogativa de função, como se um juiz de primeiro grau não pudesse ter o discernimento e a ponderação de avaliar cada situação concreta posta a seu julgamento.

De qualquer modo, este é um problema real, mas que pode ser comodamente interpretado, conforme prenunciado no Voto do Ministro Joaquim Barbosa e será visto adiante, porque as sanções previstas na LIA, para determinados casos, devem mesmo ser interpretadas e aplicadas com razoabilidade, diante da autoridade pública em julgamento, principalmente no que diz respeito às medidas cautelares de afastamento daquelas que respondam por crimes de responsabilidade no âmbito da Lei 1079/50, como é o caso do Presidente da República ou de Ministros de Estado ou de Tribunais Superiores. 
Mas o certo é que, sob o enfoque principal da punição e do controle dos atos de todos os agentes públicos, relativo exatamente à reparação civil e à multa pelos danos ou prejuízos causados, nenhuma justificativa haverá para que prevaleça a extensão inconstitucional do foro em razão da prerrogativa de função.

$\mathrm{Na}$ verdade, aquele posicionamento implica em verdadeiro retrocesso em matéria de combate à corrupção e ao controle das contas públicas de modo eficaz.

\subsubsection{A RESPONSABILIDADE CIVIL NÃO SE CONFUNDE COM A CRIMINAL OU ADMINISTRATIVA}

No momento, importa apenas rebater o argumento afirmandose que as sanções previstas para os crimes de responsabilidade (cassação dos direitos políticos e afastamento do cargo) para o exemplo citado (julgamento de ministro do STF no voto citado) por serem coincidentes em parte com as sanções previstas para os atos de improbidade, em nada impede a apuração concomitante, até porque como lembra Alexandre de Morais.

"A natureza civil dos atos de improbidade administrativa decorre da redação constitucional, que é bastante clara ao consagrar a independência da responsabilidade civil por ato de improbidade administrativa e a possível responsabilidade penal, derivadas da mesma conduta, ao utilizar a fórmula "sem prejuízo da ação penal cabível. Portanto, o agente público que, utilizando-se de seu cargo, apropria-se ilicitamente de dinheiro público, responderá, nos termos do art. $9^{\circ}$ da Lei 8429:92, por ato de improbidade administrativa, sem prejuízo da responsabilidade penal contra a administração pública, prevista no Código Penal ou na legislação penal especial"?

Ademais, é tema batido que as três esferas de responsabilidades não se misturam, e a Constituição não previu foro privilegiado para

\footnotetext{
${ }^{7}$ MORAES. Alexandre de. Improbidade Administrativa. São Paulo: Ed. Atlas, 2002, p. 322
} 
situações extra penais, e o próprio STF declarou inconstitucional (ADI 2860 ) a lei $10628 / 02$, que alterava o artigo 84 , par. $1^{\circ}$ e $2^{\circ}$, para estender o foro por prerrogativa de função para ex-autoridades e para os atos de improbidade administrativa aos agentes que já gozassem do foro privilegiado em matéria penal, seguindo orientação firme de Pontes de Miranda que aduzia "não haverá outros foros privilegiados que os instituídos pela própria constituição". ${ }^{8}$

Infelizmente, da indefinição gerada pela edição da lei supra mencionada, várias ações de improbidade se mantiveram paralisadas e todas elas que tiveram curso no foro privilegiado, conforme dispunha a lei declarada inconstitucional, foram anuladas e remetidas para os juízos de primeiro grau, causando demora injustificada e sensação maior de impunidade.

4.2. CASO SARDENBERG: UMA INTERPRETAÇÃO CONSTITUCIONAL RETRÓGRADA, SÍNTESE DO AVANÇO ÀS AVESSAS

Noutra linha, o mesmo STF, entretanto, ao decidir recentemente a Reclamação 2138 contra juiz federal substituto de Brasília que julgara procedente pedido de condenação, nos termos do art. 12 da LIA, em ação de improbidade administrativa proposta contra o ex-ministro Ronaldo Sardenberg, pela utilização indevida de avião da FAB, por maioria de votos, houve por bem entender que esta autoridade gozava de foro privilegiado, por analogia ao artigo 102, I, "c" da CF.

Em decorrência desse entendimento a Lei $n^{\circ} .8 .429 / 92$, somente deveria ter aplicação contra os demais agentes públicos, numa clara e inexplicável ofensa ao princípio da igualdade e da regra-postulado do estado democrático e do regime republicano de que quanto maior o cargo ocupado pelo agente, maior deve ser a sua responsabilidade.

0 relator do Processo ex-Ministro Nelson Jobim entendeu que o

\footnotetext{
${ }^{8}$ MIRANDA. Pontes de. Comentários a Constituição de 1967 com a Emenda n. 1, de 1969. São Paulo. RT, 1971, p.239, Tomo V.
} 
julgamento de um agente político, como ministro de Estado, por um juiz de primeira instância é incompatível com a Constituição Federal (artigo 102, I, "c"), que concede prerrogativa de foro a essas autoridades.

Lembrou Nelson Jobim que essa prerrogativa não é um privilegio pessoal dos agentes políticos, mas uma garantia para que possam exercer suas atribuições político-administrativas, que consistem em expressar a vontade soberana do Estado.

Para o ministro, os agentes políticos, além dos crimes de responsabilidade, podem ainda ser punidos pela lei penal comum, mas também desde que sejam julgados pelo juízo competente conforme o previsto pela Constituição Federal. Não caberia portanto, para o relator, a submissão do agente político a uma outra lei, permitindo-se o julgamento por autoridade inferior.

E apresenta o seguinte raciocínio:

"Se se quisesse introduzir essa mudança, ela haveria de provir de emenda constitucional. E nessa hipótese, melhor seria suprimir de vez a competência desta Corte para processar e julgar os ministros de estado, em sede penal e de responsabilidade".

0 ministro deu exemplo de situações que derivam do processamento de autoridades pela primeira instância, como o afastamento cautelar do Presidente da República, do Congresso Nacional ou mesmo do Supremo Tribunal Federal.

Em seu voto, também pela procedência da Reclamação, o ministro Gilmar Mendes ressaltou o argumento do relator no sentido de que os delitos previstos pela Lei de Improbidade são "autênticos crimes de responsabilidade". Além disso, para ele, se um agente político deve ser julgado por infrações penais comuns pelo Supremo Tribunal Federal, então não poderia ser julgado por instância inferior por in-

${ }^{9}$ STF, Informativo 471 de 11 à 15/06/2007. RCL 2138. 
frações previstas na Lei de Improbidade Administrativa, que pode acarretar penas bem mais graves que a de alguns crimes comuns. Ele citou a perda do cargo ou dos direitos políticos.

Votaram no mesmo sentido fazendo referenda ao voto de Nelson Jobim, a ministra Ellen Gracie e os ministros Maurício Corrêa e Ilmar Galvão e Cesar Peluzo.

Essa conclusão afrontou claramente o princípio da moralidade administrativa e da legalidade. E a prevalecer esse entendimento se instalaria verdadeiramente a impunidade civil do agente político pela completa impossibilidade de responder civilmente pelos seus atos capitulados na Lei $n^{\circ}$. 8.429/92, além de discriminação inconseqüente com os demais agentes públicos, que no mais das vezes apenas cumprem ordens superiores, daqueles que exatamente gozam do foro privilegiado.

A própria Constituição diz em seu artigo 37 , par. $4^{\circ}$, que os atos de improbidade administrativa têm sanções próprias e sua aplicação não implica em prejuízo a responsabilização penal, conforme linhas acima registrado.

À frente, no art. 52, Parágrafo único, resta explicitado que a condenação pela prática de crime de responsabilidade se dará sem prejuízo das demais sanções judiciais cabíveis. É certo que se a responsabilidade se operasse apenas no campo politico-administrativo, a Constituição teria excluído a possibilidade de aplicação das demais sanções judiciais.

Por felicidade, o STF vem entendendo que aquele julgamento (Reclamação 2138) não pode ter efeito para outras situações, e somente se aplica àquele caso concreto, havendo barrado várias tentativas de extensão dos efeitos daquela reclamação a outros casos de ação de improbidade para ministros, prefeitos e outras autoridades que gozam do foro privilegiado. 0 problema é que vários julgamentos de natureza similar ainda estão pendentes, leia-se o caso do Ministro Gilmar Mendes, a qualquer momento pode haver mudanças de rumos. 


\subsubsection{O VOTO REDENTOR: MINISTRO JOAQUIM BARBOSA}

Para o Ministro Joaquim Barbosa, na mesma Reclamação 2138, embasando-se no voto do Ministro Carlos Veloso, que anteriormente firmou o entendimento sobre a necessidade de preservar-se de forma ampla o princípio da moralidade, dizendo que os tipos abertos da lei de crimes de responsabilidade não abrangeriam os tipos previstos na lei de improbidade, depois de tecer considerações acerca das modalidades de improbidade elencadas na LIA, finalmente concluiu que não havia conformidade entre a conduta atribuída a Ronaldo Sardenberg e os tipos imprecisos da Lei 1079/50. Encerrou o voto de modo coerente e singelo que não se tratava a conduta do ex-ministro em hipótese de responsabilização política, logo inexistia competência para o STF julgá-lo, nos termos do art. 102, I, “c”, da CF, até porque nem ocupava mais o cargo de ministro de estado. Foi um pouco mais além o Ministro para dizer que as sanções do texto da Lei 8429/92 devem ser compatibilizadas com as sanções previstas na Lei 1079/50, especialmente as que se referirem à perda do cargo do agente passível de ser responsabilizado por crime de responsabilidade ou por infração político administrativa, sendo mais razoável que se deixe de aplicar essa pena quando se estiver diante da apuração judicial de ato de improbidade administrativa, prevalecendo as demais previstas em lei.

A melhor interpretação constitucional sobre o assunto, portanto, é aquela que não estende o foro privilegiado para os agentes políticos. 0 argumento de que não devem os agentes políticos responder pelos atos de improbidade por corresponderem os mesmos aos crimes de responsabilidade, mostra-se pífio e generalizado e não convincente, quando se sabe perfeitamente que as três instâncias de responsabilidade são completamente distintas.

Fábio Konder Comparato, citado por Alexandre de Morais, ao afirmar a inexistência de foro especial para responsabilização por atos de improbidade administrativa, assevera o seguinte: 
"a criação de foros privilegiados, em razão da função ou cargo exercitado por alguém, é sempre submetida ao princípio da reserva, de natureza constitucional ou legal. Em nenhum país do mundo, que se pretenda Estado de Direito, ou, mais ainda, Estado Democrático de Direito, nunca se ouviu dizer nem sequer sugerir que o Poder Executivo ou o Poder Judiciário tenham competência para criar prerrogativas de foro; pior ainda - o que seria inominável abuso - ninguém jamais admitiu a constitucionalidade de sistemas jurídicos onde houvesse prerrogativas de foro para os próprios membros do poder que as criava".

Afirma ainda o citado autor sobre os privilégios do foro:

"representam uma exceção ao princípio constitucional da igualdade de todos perante a lei. Em conseqüência, tais prerrogativas devem ser entendidas à justa, sem a mais mínima ampliação do sentido literal da norma. Se o constituinte não se achar autorizado a conceder a alguém mais do que a utilidade pública lhe pareceu justificar, na hipótese, seria intolerável usurpação do intérprete pretender ampliar esse benefício excepcional".10

\section{Como afirmado por Francisco Chaves dos Santos Neto:}

“A competência por prerrogativa de função tem um histórico inteiramente voltado para a jurisdição penal ordinária, sob a qual, aliás, encontra-se todo e qualquer agente público diferentemente da jurisdição penal extraordinária, própria do impeachment e só acionável em relação a determinados agentes políticos - a interpretação que daí advém, sendo o foro privilegiado uma exceção a regra geral do republicanismo, ter que ser de caráter restrito" ${ }^{11}$

Na realidade invoca-se omissão do texto constitucional para a

\footnotetext{
${ }^{10}$ MORAIS, Alexandre de. Direito Constitucional Administrativo. Editora Atlas. 3a Ed. São Paulo: 2006, p. 248

${ }^{11}$ NETO, Francisco Chaves dos Santos. Princípio da Probidade Administrativa: Regimeigualitário no julgamento dos agentes políticos. Del Rey. Belo Horizonte: 2004, p. 104.
} 
extensão do foro em matéria de ato de improbidade. Entretanto a Constituição é suficientemente clara em sua expressão ao contemplar somente os crimes comuns e de responsabilidade, para o julgamento de certos agentes, não havendo motivo nem valores éticos ou morais a justificar a extensão, ao contrário.

\section{A PEC 358 E A TENTATTVA DE RESSUSCITAR ATRAVÉS DE EMENDA O FORO PRIVILEGIADO PARA OS ATOS DE IMPROBIDADE E PARA EX-AUTORIDADES: INCONSTITUCIONALIDADE MATERIAL}

Não bastassem estas lições, em conformidade com o texto constitucional e a melhor dogmática e hermenêutica, verifica-se que a extensão do foro vai de encontro a princípios basilares da Constituição. Vai de encontro ao princípio repu blicano, cláusula pétrea implícita da Constituição, porque decorrente da soberania popular firmada pelo plebiscito que escolheu essa forma de governo, e como tal imodificável e intocável, em qualquer hipótese pelo constituinte derivado, como estão a pretender com a PEC 358, em um dos seus tópicos.

Aliás, acerca do sistema republicano, valiosa a lição da Ministra Carmem Lúcia.

“A responsabilidade está no coração do sistema democrático republicano de maneira especial. Estado sem responsabilidade jurídica e Estado sem confiança democrática e sem dignidade republicana (...) Sem responsabilidade, alarga-se o espaço da ousadia e do destemor malsão do agente menos necessário à coletividade, que è aquele que escapa ao espaço público para satisfazer, irresponsavelmente o interesse particular. Por isso é que há de se ter rigor no atendimento do princípio da responsabilidade, não apenas a do servidor público, mas, principalmente, no caso brasileiro, a do agente político e a do membro de Poder".12

\footnotetext{
${ }^{12}$ ROCHA, Carmem Lúcia Antunes. Princípios Constitucionais dos Servidores Públicos,. São Paulo: Saraiva, 1999, p. 408-409.
} 
Vai de encontro também ao princípio da igualdade, posto parecer a solução apontada na aludida Reclamação 2138 a instituição de privilégio injustificável.

No dizer de Francisco Chaves dos Anjos Neto, a instituição do foro privilegiado para o campo extrapenal, logo, para os atos de improbidade administrativa, deixando de lado os demais agentes públicos, fere de morte o princípio da igualdade, deixando sua advertência e preocupação quanto ao tema, nos termos seguintes:

\begin{abstract}
"Mais do que propiciar uma igualdade meramente formal, a ordem é assegurar uma igualdade em termos fático-substanciais, não mais se justificando, em pleno século XXI, um discurso que nem mesmo se pode apontar como liberal burguês, senão um retorno às discriminações nobiliárquicas do "ancien regime", pois não é outra coisa o que resulta quando ainda se pensa na adoção do tipo, seja a prerrogativa de foro, em jurisdição outra, que não a penal, seja o julgamento com reflexos políticos, a título de transposição do processo de impeachment para situações que fugiriam ao script dos crimes de responsabilidade" 13
\end{abstract}

E vai de encontro aos princípios da moralidade e da probidade administrativas, conforme já enunciado linhas volvidas.

Não bastasse tudo isso, a tentativa de estender o foro, seja através de interpretação constitucional de forma inconsistente e incoerente com o sistema implantado no Brasil e em vigor há mais de 100 anos, sabendo-se que o foro privilegiado e um ambiente propício para a institucionalização da impunidade, há de se ter claro que a Constituição deve ser interpretada em consonância com os princípios maiores que a regem. Não haveria motivações éticas, 1ógicas, sociológicas, jurídicas a embasar tal mudança, nem mesmo através

\footnotetext{
${ }^{13}$ NETO, Francisco Chaves dos Anjos Neto, Princípio da Probidade Administrativa. Regime Igualitário no julgamento dos agentes políticos. Editora Del Rey. Belo Horizonte: 2004, p. 174.
} 
de emenda à Constituição que se mostraria, na essência, inconstitucional.

Segundo o ensinamento de Dworkin, o fundamento da teoria constitucional consiste exatamente na fusão entre o direito constitucional e a teoria moral. Conforme o autor, ao ser citado por Miguel Nogueira de Brito:

\begin{abstract}
"Qualquer interpretação da constituição deve ser testada em duas dimensões: a primeira a dimensão do ajustamento: uma interpretação da constituição deve ser rejeitada se a pratica jurídica for inteiramente inconsistente com os princípios que a mesma recomenda. Por outras palavras, uma determinada interpretação da constituição deve ter uma base sólida na experiência jurídica. A segunda dimensão é a da justiça: se duas perspectivas sobre a melhor interpretação de uma norma constitucional se ajustam de igual modo à prática jurídica do passado, deve ser escolhida aquela que concretize princípios que nos pareçam melhor refletir os direitos e deveres morais. A constituição surge, assim, como um enunciado de ideais morais abstratos que cada geração deve reinterpretar para si própria; ou, se preferir, a constituição dá-nos conceitos abstratos em relação aos quais cada geração deve desenvolver suas próprias concepções". ${ }^{14}$
\end{abstract}

A lição de Dworkin cai como uma luva ao caso presente. Os princípios e postulados norteadores da Constituição, como o da moralidade, da probidade administrativa, do respeito aos princípios republicano e democrático, da igualdade, da legalidade, continuam atualíssimos e não se compadeceriam com uma interpretação tendente a atingi-los de forma tão grave. Ademais, a realidade social do país e o nível de esclarecimento da população não permitiriam ou pelo menos não aceitariam retrocesso tão severo no sentido de tornar uma camada da elite deste país inde ne aos espectros dos efeitos da Lei

\footnotetext{
${ }^{14}$ BRITO, Miguel Nogueira de. Originalismo e interpretação constitucional. In Interpretação Constitucional (Org.) Virgilio Afonso da Silva. Ed. Malheiros. São Paulo: 2006, p. 86
} 
8429/92. De mais a mais, a cada dia que passa faz parte da agenda mundial o combate às diversas formas de corrupção, tal qual consta da Convenção das Nações Unidas Contra a Corrupção, da qual o Brasil e signatário, havendo sido aprovada pelo Decreto Legislativo n. 348/05, havendo sido estipulado em seu artigo 30, 2, que é exigido um equilíbrio apropriado entre quaisquer imunidades ou prerrogativas jurisdicionais e a possibilidade de se proceder efetivamente à investigação, ao indiciamento e à sentença.

Não resta dúvida de que o foro priv ilegiado não promove o equilíbrio recomendado pela citada Convenção e dificulta o combate às práticas corruptas.

\section{CONCLUSÃo}

0 foro privilegiado não pode ser estendido para os atos de improbidade administrativa, visto que nestes casos está-se diante de ilícitos civis, devendo o agente ser submetido ao foro cível ordinário.

0 reconhecimento de que os atos de improbidade seriam absorvidos pelos crimes de responsabilidade em relação aos agentes políticos propiciaria a criação de uma zona de imunidade, já que as sanções para aqueles são mais brandas e uma vez terminado o mandato do agente político, caso não recebida a denuncia, a apuração da infração político-administrativa restaria prejudicada, nos termos da lei 1079/50 e a reparação do dano jamais ocorreria;

Ao mesmo tempo, a manutenção dos rigores da Lei n. 8.429/92, apenas para os servidores públicos comuns, não sujeitos ao foro privilegiado, representaria clara ofensa ao princípio da igualdade;

A extensão do foro para os atos de improbidade também implicaria em ofensa aos princípios republicano e democrático, vez que aquele baseado na responsabilidade do agente e quanto maior a função maior deve ser o grau de comprometimento com a coisa pública. 0 regime democrático estaria prejudicado na medida em que geraria generalizada desconfiança da população nas instituições, pela ausên- 
cia de punição na forma prevista em lei;

A melhor exegese constitucional é aquela que busca extrair do texto Maior os seus princípios e postulados elementares, que se aproximam o quanto possível das regras morais e éticas e que visem, o máximo à erradicação das desigualdades sociais. Num país em que há milhões de miseráveis e excluídos, a manutenção ou extensão do foro em matéria extrapenal, com ares de imunidade, representa inexplicável tergiversação e complacência com a corrupção, pela parte do hermeneuta constitucional, quando se sabe que o foro privilegiado, se não é sinônimo de impunidade, tem identidade próxima com esse conceito.

Como definido na segunda parte do voto do Ministro Joaquim Barbosa, há, de fato, dupla normatividade em matéria de improbidade, mas com objetivos distintos: a da Lei $\mathrm{n}^{\circ} .8 .429 / 92$, de natureza civil e a da Lei ${ }^{\circ}$. 1.079/50, de natureza eminentemente políticoadministrativa, que contempla os crimes de responsabilidade. Para estas a punição é mais branda: perda do cargo e a inabilitação para o exercício das funções públicas. São contudo, entidades distintas, mas que não se excluem, podendo ser processadas separadamente, ainda que desencadeadas pelo mesmo fato. Única ressalva: a pena de perda do cargo político não deve ser aplicada pelo juiz de primeira instância, porque se trata de cargo estruturante à organização do Estado, logo, configuraria incompatibilização da lógica do sistema e fator de desestabilização político-institucional, para a qual a lei de improbidade não é vocacionada.

Não debelada a idéia da extensão do foro para os atos de improbidade, restar-nos-ia sugerir a adoção da instituição do Tribunal Superior da Probidade Administrativa, conforme já há proposta na Câmara dos Deputados; ou a criação de Varas Especializadas em combate à corrupção de natureza criminal e cível e a instituição de Turmas ou Câmaras Especializadas, conforme já as há no Tribunal de Justiça do Rio Grande do Sul, além de haver na legislação a determinação para que os julgamentos de processos que envolvessem a 
matéria tivessem absoluta prioridade sobre os demais, respeitadas as situações já previstas em lei, tudo como forma de combater eficazmente esse mal que são os atos de improbidade administrativa e os crimes praticados no exercício da função pública, ou em razão da mesma.

\section{REFERÊNCIAS BIBLIOGRÁFICAS}

BRITO, Miguel Nogueira de. Originalismo e interpretação constitucional. In Interpretação Constitucional. (Org.) Virgilio Afonso da Silva. São Paulo: Malheiros, 2006.

FAORO, Raymundo. Os donos do poder. Porto Alegre. Globo, 1976.

JUNIOR, Wallace Paiva Martins. Probidade Administrativa. $3^{\text {a }}$ ed. São Paulo: Saraiva, 2006.

MIRANDA, Pontes de. Comentários à Constituição de 1967, com a emenda $n^{\circ}$. 1, de 1969.

São Paulo: RT. Tomo V.

MORAES, Alexandre de. Direito Constitucional Administrativo. $3^{\text {a }}$ ed. São Paulo: Atlas, 2006.

NETO, Francisco Chaves dos Anjos. Princípio da Probidade Administrativa: regime igualitário no julgamento dos agentes públicos. Belo Horizonte: Del Rey. 2004.

ROCHA, Carmen Lúcia Antunes. (Org.) Perspectivas do direito público: estudos em homenagem a Miguel Seabra Fagundes. Belo Horizonte. Del Rey, 1995.

ROCHA, Carmen Lúcia Antunes. Princípios Constitucionais dos Servidores Públicos. São Paulo: Saraiva, 1999,

STJ. Resp 456.649-MG. Rel. Min. Luiz Fux. DJU de 05/09/06. 
BRASIL. Artigo Jurídico. Teoria Geral do Colarinho Branco. Do foro privilegiado. Domínio Público. Disponível em < http://www. crimes docolarinhobranco.adv.br >. Acesso em: 28 fevereiro 2008.

BRASIL. Artigo Jurídico. Da inconstitucional hipertrofia do Procurador Geral da República. Disponível em <htpp://WWW.anprorg.br>> Boletim da Procuradoria da República, n. 5. 